\title{
Factor Affecting Growth of Phoma cajani Causing Stem Canker in Pigeonpea
}

\author{
S. Behera ${ }^{1 *}$, A.K. Rai ${ }^{2}$ and R. Rout ${ }^{3}$ \\ ${ }^{1}$ Department of Plant Pathology, ${ }^{3}$ Department of Economics, College of Agriculture, \\ Bhawanipatna, OUAT, Odisha-766001, India \\ ${ }^{2}$ KVK, Malkanagiri, OUAT, Odisha-764045, India \\ *Corresponding author
}

\begin{tabular}{|c|c|}
\hline & A B S T R A C T \\
\hline & \multirow{5}{*}{$\begin{array}{l}\text { Phoma cajani was isolated from stem canker infected stems and branches of pigeon pea. In } \\
\text { this study the effects of culture media, temperature and } \mathrm{pH} \text { on mycelial growth of Phoma } \\
\text { cajani was evaluated. The six isolates of Phoma cajani were grown on nine different } \\
\text { natural, semi- synthetic and synthetic media viz. potato dextrose agar, chick pea seed agar, } \\
\text { maize meal agar, nutrient agar, honey peptone agar, malt extract-peptone-dextrose agar, } \\
\text { yeast extract-dextrose-agar, czapek-dox agar and martin's agar to study the radial growth. } \\
\text { In the present study based on their growth rate, among six isolates, P1 showed better } \\
\text { growth on natural media than semi synthetic media followed by synthetic media as } \\
\text { compared to remaining five isolates. The mycelial growth was highly affected with } \\
\text { temperature. The fungus grew from } 15-30^{\circ} \mathrm{C} \text {, radial growth of the isolate } \mathrm{P} 1 \text { was found to } \\
\text { be maximum at } 25-30^{\circ} \mathrm{C} \text { and slow growth at } 15^{\circ} \mathrm{C} \text { and } 18^{\circ} \mathrm{C} \text {. The fungus grew at pH } 4-8 \text {. } \\
\text { The pH } 6 \text {, most favorable } \mathrm{pH} \text { followed by } \mathrm{pH} 7 \text { and } \mathrm{pH} 5 \text { was demonstrated in the present } \\
\text { study. }\end{array}$} \\
\hline & \\
\hline $\begin{array}{l}\text { Phoma cajani, } \\
\text { Mycelial growth, } \\
\text { Pigeonpea. }\end{array}$ & \\
\hline Article Info & \\
\hline $\begin{array}{l}\text { Accepted: } \\
\text { 21 October } 2017 \\
\text { Available Online: } \\
\text { 10 December } 2017\end{array}$ & \\
\hline
\end{tabular}

\section{Introduction}

Phoma stem canker of pigeonpea incited by Phoma cajani, when reported it was considered to be a minor disease but progressively severe in recent years causing more economic losses to pigeonpea production. The disease was repeatedly seen in experimental plots and farmers' fields causing 5-50 \% mortality in plants at maturity stage during the periodical surveys and critical observations. Pigeonpea is an important grain legume crop of rain fed agriculture in the semi-arid tropics, enriches soil through symbiotic nitrogen fixation. A short day plant with a deep root system which facilitates aeration and also enables the pigeonpea plant, tolerates drought and can be grown in areas with less than $650 \mathrm{~mm}$ annual rainfall. Pigeon pea is very nutritious, highprotein content, the leaves can be used for animal feed, woody parts can be used for firewood and it can also be used along contour barriers for preventing erosion.

Thus, pigeonpea has an important role in India. The stem canker disease is a great obstacle in the way. The objective of this study was to provide information on effects of culture media and various environmental factors including temperature and $\mathrm{pH}$ on mycelial growth of Phoma cajani. 


\section{Materials and Methods}

\section{Effect of different nutritional status of media on radial growth of Phoma cajani}

Nutritional requirement of various fungi differs and no universal medium can be used to culture all fungi. The six isolates of Phoma cajani were grown on nine different natural, semi- synthetic and synthetic media viz. potato dextrose agar, chick pea seed agar, maize meal agar, nutrient agar, honey peptone agar, malt extract-peptone-dextrose agar, yeast extract-dextrose-agar, czapek-dox agar and martin's agar to study the radial growth. A mycelial disc (5 mm dia.) cut with the help of cork borer from the periphery of $6-7$ days old culture was transferred to the centre of petri plates containing $20 \mathrm{ml}$ of different media and petriplates were incubated at $25 \pm$ $2^{0} \mathrm{C}$. The experiment was repeated with 3 replications. The colony diameter was determined by measuring the linear growth of the fungus for each of its isolate in the respective plates (Average of three replications) at the interval of $24 \mathrm{hrs}$ till they reached periphery of the plates in each treatment. Then average growth (per day) of fungus was calculated (Scheepens and Fehrmann, 1978).

\section{Effect of different temperature on the mycelial growth}

The six isolates of Phoma cajani were grown on PDA medium to determine optimum temperature for radial growth of the pathogen. A mycelial disc ( $5 \mathrm{~mm}$ dia.) cut with the help of a cork borer from the periphery of $6-7$ days old culture of pathogen grown in petriplates of PDA was placed in the centre. These petriplates were incubated at $15^{\circ}, 18^{0}$, $20^{\circ}, 22^{0}, 25^{\circ}, 28^{\circ}$ and $30^{\circ} \mathrm{C}$ temperatures respectively. The experiment was replicated three times. Radial growth of the fungus was recorded at an interval of $24 \mathrm{hrs}$ till it reached the periphery of each petriplate. Then average growth (per day) of fungus was calculated.

\section{Effect of different $\mathrm{pH}$ on the radial growth of pathogen}

Six isolates which were grown on PDA medium at temperature $25^{0} \pm 2^{0} \mathrm{C}$ to determine suitable $\mathrm{pH}$ for radial growth of the fungus. After preparation of PDA medium, their suitable volumes were adjusted at different $\mathrm{pH}$ level 4, 5, 6, 7 and 8 using $1 \mathrm{~N}$ $\mathrm{HCl}$ or $1 \mathrm{~N} \mathrm{NaOH}$. For measuring the $\mathrm{pH}$ of a solution, the $\mathrm{pH}$ meter was calibrated before use by means of a standard solution. The meter should be calibrated with the solution whose $\mathrm{pH}$ is close to that under test. The beaker containing test solution must be thoroughly stirred before measuring the $\mathrm{pH}$. A magnetic stirrer is probably most convenient. Different $\mathrm{pH}$ was obtained by adding appropriate amount of acid and basic solution in the medium. The electrodes appropriately dipped into the test solution and reading noted. After use, the electrode was washed thoroughly with distilled water and calibrated (Dhingra and Sinclair, 1995). Media were sterilized, poured in petridishes. Then a mycelial disc ( $5 \mathrm{~mm}$ dia.) was cut with the help of cork borer from the growing edge of 6-7 days old culture of the fungus grown on PDA at different $\mathrm{pH}$ range of 4, 5, 6, 7 and 8 . The petriplates were then incubated at $25^{0} \pm$ $2^{0} \mathrm{C}$. The experiment was also conducted with three replicate. The radial growth of fungus was recorded at an interval of $24 \mathrm{hrs}$ till it reached the periphery of each petriplate. Average growth (per day) of fungus was also calculated

\section{Results and Discussion}

\section{Effect of different media}

Growth rate of six isolates of the test fungus growing in different media was recorded at 24 
hrs interval till they reached periphery of the plates in each treatment. In the present study based on their growth rate, among six isolates, P1 showed better growth on natural media (potato dextrose agar, chick pea seed agar and maize meal agar) than semi synthetic media (nutrient agar, honey peptone agar, malt extract-peptone-dextrose agar and yeast extract-dextrose-agar) followed by synthetic media (czapek-dox agar and Martin's agar) as compared to remaining five isolates (Table 1).

Among the natural media, PDA was the best medium for the growth of the pathogen. Present findings are similar to the observations of KueiMai (2000) who deduced that PDA medium was best among the tested media and further reported that Phoma wasabiae produced pycnidia on the same medium. Lopez Roza (1969) told that the fungus grew well on potato-dextrose agar, corn-meal agar, oat-meal agar, and pigeonpea-pod agar.

In the present study among synthetic media average radial growth of CZK $(17.7 \mathrm{~mm})$ was more than that of MA $(10.88 \mathrm{~mm})$. Our findings are in accordance with the observations of Tosi and Zazzerini (1994) were tested various culture media (PDA, V8, malt agar, Czapek agar and carrot agar) against Phoma incompta on olive plant and found that growth and sporulation were best on V8 and Czapek agar than PDA medium.

Wolcan and Ronceros (1990) elucidated the interaction of 4 culture media (PDA, V8 juice agar (V8A), Czapek agar (CA) and sweetpea agar (SA) on Phoma medicaginis var. pinodella growth, sporulation and cultural characteristics and concluded that SA gave the highest sporulation rate.

\section{Effect of different temperature}

Growth rate of 6 isolates of the test fungus growing at different temperatures on PDA was recorded at $24 \mathrm{hrs}$ interval. The mycelial growth was highly affected with temperature. The radial growth of the isolate P1 was found to be maximum at $25-30^{\circ} \mathrm{C}$ in the present study. These observations help to find optimum temperature for the growth of pathogen (Table 2).

Table.1 Effect of different media on the mycelial growth of P. cajani

\begin{tabular}{|l|c|c|c|c|c|c|}
\hline \multirow{2}{*}{ Media } & \multicolumn{6}{|c|}{ Average radial growth (mm/day)* } \\
\cline { 2 - 7 } & P1 & P2 & P3 & P4 & P5 & P6 \\
\hline $\begin{array}{l}\text { Potato Dextrose Agar } \\
\text { (PDA) }\end{array}$ & 25 & 18 & 17 & 23 & 21 & 22 \\
\hline $\begin{array}{l}\text { Chick Pea seed Agar } \\
\text { (CPSA) }\end{array}$ & 19.75 & 18.75 & 17.75 & 15.75 & 17 & 17.5 \\
\hline Maize meal Agar (MMA) & 20 & 15.5 & 13.75 & 15.25 & 19.25 & 14.25 \\
\hline Nutrient Agar (NA) & 18 & 14.5 & 14.75 & 15.5 & 17.25 & 17.5 \\
\hline Honey peptone Agar (HPA) & 17 & 14.8 & 12.6 & 15.2 & 16.4 & 14 \\
\hline $\begin{array}{l}\text { Malt extract-peptone- } \\
\text { dextrose-agar (MEPDA) }\end{array}$ & 18.5 & 15.75 & 16.5 & 17.25 & 15.5 & 17 \\
\hline $\begin{array}{l}\text { Yeast extract-dextrose-agar } \\
\text { (YEDA) }\end{array}$ & 19.25 & 17.25 & 16.25 & 15.25 & 13.75 & 15.75 \\
\hline Czapek - dox Agar (CZK) & 17.6 & 16 & 16.8 & 15.6 & 16 & 16.4 \\
\hline Martin's Agar (MA) & 10.88 & 9.88 & 10.25 & 10.63 & 9.75 & 10.38 \\
\hline
\end{tabular}

*Measured 4 days after inoculation. 
Table.2 Effect of different temperature on the mycelial growth of $P$. cajani

\begin{tabular}{|l|c|c|c|c|c|c|}
\hline \multirow{2}{*}{$\begin{array}{c}\text { Temperature } \\
\text { Isolates }\end{array}$} & \multicolumn{7}{|c|}{ Average radial growth (mm/day)* } \\
\cline { 2 - 7 } & P1 & P2 & P3 & P4 & P5 & P6 \\
\hline $15^{\circ} \mathrm{C}$ & 8 & 7.55 & 7.27 & 7.36 & 7.18 & 7.27 \\
\hline $18^{\circ} \mathrm{C}$ & 8.8 & 8.5 & 8.1 & 8.6 & 8 & 8.7 \\
\hline $20^{\circ} \mathrm{C}$ & 9.67 & 9.22 & 9.33 & 9 & 9.11 & 8.78 \\
\hline $22^{\circ} \mathrm{C}$ & 16 & 15.2 & 15 & 13.8 & 14.8 & 15 \\
\hline $25^{\circ} \mathrm{C}$ & 29 & 28.33 & 27.67 & 25 & 25.67 & 26.33 \\
\hline $28^{\circ} \mathrm{C}$ & 21.5 & 18.75 & 17.5 & 20.75 & 19.75 & 21.25 \\
\hline $30^{\circ} \mathrm{C}$ & 21.25 & 20.75 & 20.75 & 18.75 & 19.25 & 20 \\
\hline
\end{tabular}

*Measured 4 days after inoculation.

Table.3 Effect of different $\mathrm{pH}$ on the mycelial growth of $P$. cajani

\begin{tabular}{|l|l|l|l|l|l|l|}
\hline \multirow{2}{*}{ pH } & \multicolumn{7}{|c|}{ Average radial growth (mm/day)* } \\
\cline { 2 - 7 } & $\mathbf{P 1}$ & $\mathbf{P 2}$ & $\mathbf{P 3}$ & $\mathbf{P 4}$ & $\mathbf{P 5}$ & P6 \\
\hline $\mathbf{4}$ & 16 & 15.8 & 15 & 14.8 & 14.6 & 14 \\
\hline $\mathbf{5}$ & 19.75 & 17.75 & 18.25 & 17.5 & 18.25 & 18.25 \\
\hline $\mathbf{6}$ & 28.33 & 27.33 & 23.67 & 25 & 25.67 & 24.33 \\
\hline $\mathbf{7}$ & 26.67 & 24.33 & 25 & 26 & 24.67 & 26 \\
\hline $\mathbf{8}$ & 18.75 & 17 & 16 & 17.25 & 14.5 & 17.25 \\
\hline
\end{tabular}

*Measured 4 days after inoculation.

In the present investigation it was evident that when temperature ranges from $25-30^{\circ} \mathrm{C}$ in second week of July, infection of stem canker observed but infection was slow or checked during winter season again in February to March as the temperature raised disease become severe, therefore temperature played a vital role in disease development. In the past Nebane and Ekpo (1995) investigated the effects of temperature on radial growth and pycnidium production of cowpea (Vigna unguiculata) isolates (PB1, PB2, PB3) of Phoma bakeriana in vitro and found that maximum growth and pycnidium production occurred at $25^{\circ} \mathrm{C}$. The optimum temperature range was $20 \mathrm{C}$ to $28^{\circ} \mathrm{C}$ for the growth of Phoma as deduced by KueiMai (2000). Roustaee et al., (2001) evaluated the growth of 17 isolates of Phoma macdonaldii, the causal agent of sunflower black stem and investigated for response to temperature and for morphology and asexual morphogenesis (pycnidiogenesis and pycnidium size). They concluded that the optimum temperature varied between 20 and $30^{\circ} \mathrm{C}$ and radial growth was slowest at 5 and $35^{\circ} \mathrm{C}$.

However the optimum temperature for growth of pathogen was $20^{\circ} \mathrm{C}$ as elucidated by Tosi and Zazzerini (1994) but in the present study none of the isolates were found to grow at best at that temperature.

\section{Effect of different $\mathrm{pH}$}

Growth pattern of six isolates of the test fungus growing at different $\mathrm{pH}$ on PDA at 25 $\pm 2^{0} \mathrm{C}$ was recorded at $24 \mathrm{hrs}$ interval. It was found that like media and temperature among six isolates, average radial growth of isolate $\mathrm{P} 1$ was superior than remaining five isolates on each $\mathrm{pH}$ level. The $\mathrm{pH} 6$, most favorable $\mathrm{pH}$ followed by $\mathrm{pH} 7$ and $\mathrm{pH} 5$ was demonstrated in the present study. However 
Tosi and Zazzerini (1994) found that the opt. $\mathrm{pH}$ for the growth of $P$. incompta on all tested media ranged from 6.5-7.5 and the same has now been confirmed in our study (Table 3 ).

According to Roustaee et al., (2001) for 17 isolates of Phoma macdonaldii, the causal agent of sunflower black stem, the optimum $\mathrm{pH}$ for growth was between 4 and 5 but in the present study none of the isolates were found to grow at best at that $\mathrm{pH}$.

From the above three observations i.e. influence of media, temperature and $\mathrm{pH}$ it was confirmed that, average radial growth of isolate $\mathrm{P} 1$ was maximum on PDA medium at $25^{\circ} \mathrm{C}$ at $\mathrm{pH} 6$.

\section{References}

Dhingra, O.D. and Sinclair, J.B. 1995. Basic plant pathology methods. 2nd ed. Boca Raton, FL: CRC Press. 267-285 pp.

KueiMai, L.C.T.W. 2000. Factors affecting pycnidial production and pycnidiospore germination of Phoma wasabiae, the causal agent of wasabi. Plant Pathology Bulletin, 9(3): 99-106.

Lopaz Roza, J.H. 1969. Phoma sp, the causal agent of pigeonpea canker. Phytopathology, 59: 1348.

Nebane, C.L.N. and Ekpo, E.J.A. 1995. Effect of culture media, temperature and light on radial growth and pycnidium production of cowpea isolates of Phoma bakeriana. Annals of Applied Biology, 121: 3, 537-544.

Roustaee, A., Costes, S., DechampGuillaume, G. and Barrault, G. 2001. Phenotypic variability of Leptosphaeria lindquistii (anamorph: Phoma macdonaldii), a fungal pathogen of sunflower. British Society for Plant Pathology, 49: 227-234.

Scheepens, P.C. and Fermann, 1978. Cultivation of Phytophthora on defined nutrient media. Phytopathology, 93: 126-136.

Tosi, L. and Zazzerini, A. 1994. Phoma incompta, a new olive parasite in Italy. Petria, 4(2): 161-169.

Wolcan, S.M. and Boggio Ronceros, R. 1990. The effects of light regimes, temperatures and culture media on sporulation, growth and cultural characteristics of Ascochyta pinodella Jones. Turrialba, 40(3): 391-396.

\section{How to cite this article:}

Behera, S., A.K. Rai and Rout, R. 2017. Factor Affecting Growth of Phoma cajani Causing Stem Canker in Pigeonpea. Int.J.Curr.Microbiol.App.Sci. 6(12): 2991-2995. doi: https://doi.org/10.20546/ijcmas.2017.612.349 